\title{
Pemrograman arsitektur gereja st. Fransiskus Xaverius Kidul Loji Yogyakarta
}

\author{
YD. Krismiyanto*, 1 \\ a Program Studi Arsitektur, Fakultas Teknik, Universitas Atma Jaya Yogyakarta \\ 1 email penulis pertama : dwikora.krismiyanto@uajy.ac.id
}

\begin{tabular}{ll}
\hline Informasi artikel & ABSTRAK \\
\hline Sejarah artikel: & Gereja Kidul Loji yang juga dikenal dengan Gereja St. Fransiskus \\
Diterima & Xaverius Kidul Loji merupakan salah satu gereja tertua di Yogyakarta dan \\
Revisi & menjadi suatu kebanggaan di hati mengingat sejarah dan perkembangan \\
Dipublikasikan & umat Paroki ini. Dengan jumlah umat yang terus bertambah banyak perlu \\
\hline Kata kunci: & adanya pengembangan dari segala segi, tidak hanya dari administrasi \\
Bentuk-Simbolik & parokial tapi juga bangunan Gerejanya. Rencana ini teruskan ke \\
Transformasi & Keuskupan Agung Semarang supaya selain sekedar renovasi ataupun \\
Dimensi Formal & memperluas gereja lama namun supaya ada kebijakan dari Keuskupan \\
Dimensi Transendental & Agung Semarang (sebagai pusat provinsial gereja Katolik Jawa Tengah) \\
& untuk menjadikan gereja Kidul Loji sebagai gereja pusat untuk regio \\
& Yogyakarta atau menjadi: "Gereja Katolik dan Kantor Pusat Vikaris \\
& Episkopalis Yogyakarta. \\
\hline Key word: & ABSTRACT \\
\cline { 2 - 3 } $\begin{array}{l}\text { Symbolic Forms } \\
\text { Transformations }\end{array}$ & $\begin{array}{l}\text { Kaverius Kidul Loji is one of the oldest churches in Yogyakarta and is a } \\
\text { Formal Dimensions } \\
\text { Transcendental Dimensions }\end{array}$ \\
source of pride in the heart given the history and development of the \\
parishioners. With a growing number of people there needs to be \\
development in all aspects, not only from the parochial administration but \\
also the church building. This plan is forwarded to the Archdiocese of \\
Semarang so that in addition to just renovating or expanding the old \\
church, there is a policy of the Archdiocese of Semarang (as the provincial \\
center of the Central Java Catholic Church) to make the Kidul Loji church \\
the central church for the Yogyakarta region or become: "Catholic Church \\
and Yogyakarta Vicaris Episcopalis Headquarters.
\end{tabular}

Copyright $\odot 2021$ Universitas Widya Mataram Yogyakarta. All Right Reserved

\section{Pendahuluan}

\subsection{Latar Belakang}

Semakin berkembangnya umat di Paroki Santo Fransiskus Xaverius, Kidul Loji, Yogyakarta, selain membanggakan hati, juga menuntut perlunya pengembangan segi lain. Salah satunya adalah tempat yang memadai bagi umat untuk beribadat di Gereja. Pada saat ini, kebutuhan akan tempat beribadat tersebut dirasakan kurang, karena kapasitas gereja hanya memuat 400 orang. Hal ini dapat dilihat dari penuhnya bangku gereja pada saat kebaktian Misa, sehingga banyak umat harus berdiri atau terpaksa duduk di halaman luar gereja.

Keadaan fisik gedung gereja juga sangat memprihatinkan. Banyak tembok yang keropos dimakan usia. Hal ini dapat dipahami karena Gereja Kidul Loji merupakan salah satu gereja tertua di Daerah Istimewa Yogyakarta. Bila keadaan ini tidak segera ditangani dapat membahayakan umat, oleh karenanya umat Katolik Paroki Kidul Loji menginginkan dapat memiliki gereja yang lebih luas dan kokoh, sehingga dapat mendukung proses bersama dalam pembekalan rohani. Dengan demikian pengembangan kompleks Gereja Santo Fransiskus Xaverius Kidul Loji sangat diperlukan. Berdasarkan keadaan tersebut, Dewan Paroki memutuskan untuk memperluas gedung Gereja St.Fransiskus Xaverius.

Pada saat rencana ini disampaikan kepada Keuskupan Agung Semarang terjadilah pengembangan rencana yang lebih jauh dari sekedar renovasi ataupun memperluas gereja lama. Tampaknya ada kebijakan dari Keuskupan Agung Semarang (sebagai pusat provinsial gereja Katolik Jawa Tengah) 
untuk menjadikan gereja Kidul Loji sebagai gereja pusat untuk regio Yogyakarta atau menjadi: "Gereja Katolik dan Kantor Pusat Vikaris Episkopalis Yogyakarta.

\subsection{Sejarah Singkat Gereja Kidul Loji}

Gereja St.Fransiskus Xaverius Kidul Loji (untuk selanjutnya disebut Gereja Kidul Loji) pada mulanya didirikan untuk memenuhi kebutuhan prajurit Belanda di Yogyakarta. Disebut Kidul Loji karena gereja itu terletak di sebelah selatan Benteng (Loji) Vredeburg, markas prajurit Belanda. Tidak ada catatan resmi berkaitan dengan pendirian gereja Kidul Loji. Namun demikian dalam buku baptis dituliskan bahwa pada tanggal 3 Desember 1812 telah dibaptis sebanyak 32 orang.

Sejak saat itu umat Katolik di sekitar Kidul Loji semakin bertambah. Pada tahun 1865 terhitung ada 950 orang, sebagian besar tinggal di sekitar atau di dalam Beteng Vredeburg. Mereka dibina oleh seorang pastor Jesuit, yakni Pastor Yohanes Baptista Polinckx. Pastor Polinckx pula yang memulai upaya pembangunan pastoran dan gereja. Pembangunan itu selesai pada tahun 1869 dan diresmikan pada tanggal 7 Juni 1871.

Secara organisatoris, perkembangan Gereja Kidul Loji dapat digambarkan sebagai berikut: pada saat pendudukan Belanda gereja Kidul Loji digunakan sebagai gereja Belanda, sesudah masa pendudukan Jepang, status Gereja Kidul Loji adalah sebagai gereja stasi yang menjadi bagian dari Paroki Bintaran. Tahun 1968 Kidul Loji diakui sebagai paroki tersendiri dengan pastor paroki Aloysius Wahyasudibya Pr. Setelah Pastor Aloysius Wahyasudibya Pr., reksa pastoral paroki Kidul Loji diserahkan kepada pastor-pastor Yesuit sampai pada tahun 1989. Mulai tahun itu pula reksa pastoral paroki Kidul Loji dipercayakan kepada Pastor Suhartana Pr. Pada saat penelitian ini ditulis, pastor paroki dijabat oleh Romo Ignatius Jayasewaya yang sekaligus menjadi Vikaris Episkopalis Gereja Katolik Yogyakarta.

Paroki Kidul Loji terus berkembang. Pertambahan umat semakin banyak. Untuk itu, pada tahun 1975 diadakan pemugaran gereja yang terbatas pada pembuatan pintu samping kanan dan kiri, serta dinding depan dan dinding panti imam serta altar diberi wajah artistik atas saran room YB.Mangunwijaya. Dengan demikian, bagian dalam gereja tetap utuh dan luas gereja tidak berubah.

Pada tahun 1992, Keuskupan Agung Semarang menyetujui rencana renovasi dan perluasan gedung Gereja St. Fransiskus Xaverius Kidul Loji Yogyakarta. Bahkan Uskup menyarankan agar gereja baru diharapkan dapat menampung 1000 umat. Sasaran ini diberikan untuk menghadapi perkembangan umat Paroki Kidul Loji di masa mendatang, lebih mengingat Gereja Kidul Loji saat ini menjadi tempat tinggal Vikaris Episkopalis (Vikep) untuk Daerah Istimewa Yogyakarta dan menjadi pusat kegiatannya. Karena itu, Dewan Paroki mulai membentuk Panitia Pembangunan dan Pengembangan Gereja pada tanggal 18 Juli 1993.

\section{Metode}

Penelitian difokuskan pada Arsitektur Gereja St. Fransiskus Xaverius Kidul Loji berikut dinamika jemaat Gereja baik Hierarki dan Jemaat Awam. Sebagai Arsitek yang dilibatkan pada setiap tahapan perencanaan dan perancangan maka Peneliti juga melakukan secara aktif (Riset Aksi) dan Bersama umat melaksanakan Desain Partisipatif. Pendekatan Rasionalistik Kualitatif diterapkan pada kajian awa, pengamatan, analisis dan sintesis Pemrograman Arsitektur untuk Gereja St. Fransiskus Xaverius Kidul Loji Yogyakarta.

\section{Hasil dan pembahasan}

\section{RENCANA PENGEMBANGAN DAN PEMROGRAMAN \\ a. Rencana Pengembangan Gereja Kidul Loji}

Sejak mendapat lampu hijau dari Keuskupan Agung Semarang, Dewan Paroki bersama romo Paroki mempersiapkan terlebih dahulu suatu rencana pengembangan yang strategis. Rencana ini diperlukan agar panitia mempunyai arah dan pedoman dalam melaksanakan pembangunan gereja. Pada intinya, Gereja St. Fransiskus Xaverius Kidul Loji akan dikembangkan dari gereja paroki-al menjadi gereja regional. Secara hirarkis, paroki adalah struktur gereja yang paling kecil, diikuti kemudian gereja regional, gereja provinsial dan akhirnya gereja universal yang berpusat di Vatikan, Roma.

Paroki sendiri terdiri atas wilayah-wilayah dan lingkungan-lingkungan. Gereja yang terdapat di 
wilayah disebut Stasi, sedangkan di lingkungan pada umumnya umat beribadat di rumah rumah. Jadi yang disebut gereja adalah dalam lingkup parokial. Gereja Katedral umumnya menandai adanya gereja provinsial. Gereja Katedral Jakarta misalnya, adalah pusat gereja provincial Keuskupan Agung Jakarta. Gereja universal mempunyai gereja terbesar dan termegah yang disebut dengan nama Basilika. Basilika Santo Petrus di Vatikan dengan demikian adalah Pusat Gereja Katolik Universal.

Secara fisik dapat dikatakan gereja terkecil adalah rumah-rumah jemaat (lingkungan atau lokal), stasi (wilayah), gereja (parokial), gereja Kevikepan (regional), Katedral (provinsial) dan Basilika (universal) sebagai gereja terbesar. Ada satu sebutan lagi untuk gereja kecil yaitu kapel, biasanya dipakai untuk menyebut gereja stasi di wilayah atau di dalam biara.

Kalau menelusuri perjalanan sejarah gereja Kidul Loji ini maka terlihat peningkatan peran dari gereja untuk skala lingkungan yang sifatnya lokal (bagi para prajurit Belanda di Benteng Vredeburg), lalu sebagai gereja stasi dalam skala wilayah Loji kecil dan sekitarnya dan menjadi bagian dari paroki Bintaran, kemudian menjadi gereja paroki sendiri yang terpisah dari paroki Bintaran, dan sekarang sebagai gereja regional.

Menjadi gereja dalam skala regional artinya membawahi semua gereja paroki yang ada di Kevikepan Yogyakarta yang meliputi area seluas propinsi Daerah Istimewa Yogyakarta. Sebetulnya, gereja paroki Bintaran untuk beberapa lama dipersiapkan untuk menjadi gereja regional namun karena alasan lokasi dan peran simbolisnya, gereja Kidul Loji akhirnya kemudian dipilih untuk mengambil peran ini.

Selain letaknya yang amat strategis dan simbolis, ada perkembangan baru yang terjadi di gereja Kidul Loji yaitu berkaitan dengan kepindahan percetakan Kanisius ke Deresan, Demangan. Tanah yang semula ditempati oleh percetakan diwakafkan seluruhnya kepada pihak gereja dalam hal ini Keuskupan Agung Semarang sebagai pemilik gereja Kidul Loji. Dengan tambahan site ini memungkinkan pengembangan gereja mengingat lahan semula hanya cukup untuk gereja dan pastoran. Sekarang, dengan tambahan luasan yang cukup berarti dapat dibangun fasilitas penunjang lain yang dibutuhkan baik lewat pengembangan horisontal (perluasan bangunan) maupun pengembangan vertikal (bangunan bertingkat).

Rencana pengembangan ini membawa konsekuensi hirarkis, organisatoris, sistem aktivitas, dan akhirnya sistem setting arsitektur dan lingkungannya. Secara hirarkis, kini reksa pastoral gereja Kidul Loji langsung di bawah Keuskupan Agung Semarang dan membawahi paroki-paroki di seluruh Yogyakarta. Secara organisatoris, gereja Kidul Loji harus tetap menjadi gereja paroki bagi jemaat di paroki Kidul Loji itu sendiri sementara pada saat yang sama juga menjadi 'gereja pusat' bagi gerejagereja lain yang ada di Yogyakarta.

\section{b. Rencana Pemrograman Arsitektur}

Dari latar belakang rencana pengembangan yang diuraikan di atas dapat dibayangkan peningkatan dan perkembangan aktivitas di gereja Kidul Loji yang berkaitan dengan peningkatan peran gereja Kidul Loji. Jumlah pengunjung akan lebih banyak dan beragam sementara skala pelayanan tidak hanya terbatas pada liturgi dan peribadatan. Dari segi setting arsitektur dan penataan lingkungannya, diusulkan suatu rencana pemrograman berikut;

1. Pengembangan Fungsi dan Peran Gereja Parokial menjadi Gereja Regional dengan skala pelayanan 2. Penyediaan Fasilitas Pelayanan Gerejani untuk jemaat Katolik Yogyakarta berupa: Gereja sebagai tempat ibadat, Pastoran sebagai tempat tinggal para pastor, Perkantoran untuk organisasi awam maupun pelayanan jemaat, Gedung Serbaguna untuk pertemuan jemaat di luar peribadatan

\section{PENDEKATAN ARSITEKTUR DALAM GEREJA \\ a. Gereja Sebagai Jemaat}

Perancangan Arsitektur meliputi tahap-tahap pemrograman, perencanaan dan perancangan. Pemrograman terutama berkaitan dengan pengumpulan, pengaturan dan pengelolaan informasi yang diperlukan untuk perencanaan dan perancangan. Mengingat struktur gereja yang kompleks baik dari segi organisasi gereja itu sendiri maupun permasalahan yang harus dihadapi dan diselesaikan maka diperlukan upaya dan proses pemrograman yang tidak sederhana, yang menuntut prosedur-prosedur yang lebih luas dan teknik-teknik yang memadai. Bahkan sebelum menerapkan prosedur, metode dan cara tertentu perlu dilakukan suatu pendekatan yang lebih luas untuk mengenali klien, yaitu: Gereja, beserta unsur-unsur lain yang terlibat dalam pemrograman ini.

Kata GEREJA sering digunakan untuk menunjuk bangunan di mana jemaat berkumpul, maka bangunan gereja dapat membantu kita untuk memahami tujuan-tujuan yang mau dicapai oleh jemaat yang membangunnya dan bagaimana cara-cara gedung itu digunakan dan iman kepercayaan yang mau diungkapkan lewat bangunan gereja. Tetapi arti gereja yang kedua dan lebih penting, Gereja adalah sekelompok orang yang beriman, ambil bagian untuk hidup baru bersama dan melalui Yesus Kristus. 
Sekelompok kecil umat Kristen yang berdoa diam-diam di sebuah gereja kecil di pedesaan sama nilainya dengan sejumlah besar jemaat yang bernyanyi meriah di dalam Katedral kota metropolitan.

Jadi jemaat adalah sosok gereja yang sebenarnya. Dalam sejarah gereja sampai hari ini ada dua aliran besar: Gereja Katolik dan Gereja Kristen Protestan. Kekhususan dan kekhasan Gereja Katolik adalah mengakui Paus sebagai pemimpin gereja tertinggi di dunia dan bertempat tinggal di Vatikan Roma. Semula hanya ada satu gereja. Namun sejak pecahnya gerakan gereja Protestan dan Reformasi di Eropa berkembanglah aliran-aliran baru gereja kristen. Gereja yang pada saat itu identik dengan negara-negara dan kerajaan-kerajaan di Eropa mendapatkan pelajaran berharga, akhirnya gereja memisahkan diri dari politik dan kekuasaan. Perjalanan jatuh bangun selama 2000 tahun jemaat gereja Katolik membentuk struktur organisasi yang solid tetapi juga adaptif terhadap perubahan dan perkembangan yang terjadi di masyarakat. Kepemimpinan yang mulanya sangat primordial dan sepihak sekarang berkembang semakin demokratis dan partisipatif.

Dalam Konstitusi Liturgi yang menjadi pedoman setiap paroki, yang juga diterapkan di Gereja Kidul Loji, disebutkan: "Untuk menilai karya-karya seni hendaknya para Uskup mendengarkan Panitia keuskupan untuk Kesenian Liturgi, dan - bila perlu - juga pakar-pakar lain, serta Panitia-panitia yang disebut dalam art. 44, 45, 46. Hendaknya para Pimpinan Gereja menjaga dengan saksama, jangan sampai perlengkapan ibadat atau karya-karya seni, yang merupakan hiasan rumah Allah, dipindahtangankan atau rusak" (Konstitusi Liturgi no.126).

Pakar dalam konteks ini adalah Arsitek yang ditunjuk selain itu juga perlu didampingi oleh pakar liturgi gereja sejak dalam pemrograman, perencanaan dan perancangan, sampai pada pelaksanaan pembangunan. Jemaat setempat - biasanya diwakili oleh beberapa orang yang kompeten - merupakan unsur dasar dan utama dalam tim tersebut. Tugas wakil-wakil jemaat ini adalah memberikan masukan kepada arsitek dan para perencana tentang gambaran mengenai gereja dan makna gereja di tengah masyarakat setempat.

Seorang arsitek yang baik akan terbuka terhadap aspirasi jemaat, tetapi juga cukup tegas untuk tidak hanyut dalam keinginan dan selera dangkal mereka, dan arsitek tetap dituntut untuk mempunyai keberanian dan kebebasan menawarkan penyelesaian yang kreatif. Yang penting, arsitek harus menangkap gambaran, corak dan maksud perayaan liturgi sebagai inti dan tuntutan dasar sebuah gereja. Dalam hal ini ia harus terus-menerus mengadakan konsultasi dengan para pastor dan para pakar yang terlibat serta pendapat dari jemaat. Pada intinya arsitek harus berpusat pada jemaat. Dari himpunan jemaat inilah rumah ibadat kaum beriman mendapat sebutan gereja. Karena sifatnya sebagai persekutuan atau perkumpulan inilah maka pendekatan maupun mekanisme konsultatif dan partisipatif memang sudah implisit ada dalam gereja Katolik. Hal itu tidak lain merupakan konsekuensi dari aspek sosial dari gereja.

Dengan menempatkan diri pada situasi sosial diharapkan mendapatkan pemahaman yang lebih baik sebelum mengusulkan suatu program tata ruang dan bangunan gereja. Dan setelah melihat struktur organisasi gereja dan struktur kerja antara jemaat, panitia, hirarki dan Dewan Paroki maupun unsurunsur lain yang terlibat, maka langkah berikut adalah mengkaji proses pemrograman arsitekturnya. Namun sebelum sampai pada kajian tentang proses pemrograman baiklah melihat sekilas arsitektur gereja Katolik untuk memperluas wawasan dan kajian permasalahan gereja secara umum pada saat ini.

\section{b. Arsitektur Gereja Katolik Di Indonesia}

Arsitektur gereja Katolik seperti dijumpai sekarang ini dapat dikatakan berwajah banyak. Tidak ada bentuk-bentuk arsitektural tertentu yang dapat mengklaim: inilah bentuk arsitektur khas gereja Katolik. Bangsa mana pun maupun kurun jaman kapan pun tidak mungkin menghayati iman dan agamanya secara tuntas. Selalulah hanya beberapa aspek atau titik berat yang intens dihayati atau disukai, sedangkan aspek-aspek lainnya tidak diingkari namun nyatanya kurang ditekankan memang selera dan karakter manusia maupun zaman tidak dapat dan tidak perlu sama.

Pada abad abad awal menyebarnya agama Kristen, orang-orang Kristen beribadat di rumah, sinagoga, atau di tempat apa saja yang dapat dipakai untuk pertemuan. Di dalam abad-abad berikut, ketika Gereja menjadi agama negara Romawi-Bizantium, bentuk-bentuk arsitektural gereja mengambil warisan kebudayaan Yunani-Romawi yaitu bangsal perjumpaan dengan lambang jalan. Kemudian pada abad pertengahan tampil gaya Gotik yang mengambil lambang cahaya (Mangunwijaya, 1988).

Gaya gotik bertahan sampai abad 19 di Eropa, di mana gereja-gereja yang dibangun hampir seragam. Sesudah Perang Dunia I, gereja-gereja yang dibangun menawarkan perubahan untuk lebih mengungkapkan seni religius. Setelah Perang Dunia II, terjadi gairah membangun gereja dengan gaya modern dengan mengandalkan kemampuan teknik. Pada abad ke 20, arsitektur gereja kembali kepada semangat gereja perdana yaitu gereja sebagai tempat jemaat berkumpul dan lambang persaudaraan. Bersamaan dengan peranan gereja dalam masyarakat yang berubah terjadi pembaharuan yang 
bercirikan dua hal: ibadat yang menjadi lebih sederhana tetapi jelas dan suasana persaudaraan. Adapun ciri khas bangunan-bangunannya adalah keberagaman.

Khusus di Indonesia tersedia bermacam-macam model, baik yang berasal dari 'Barat' maupun gaya bangunan dari budaya 'setempat yang menawarkan kemungkinan-kemungkinan baru. Bangunan gereja memang tidak sama dengan gereja itu sendiri, tetapi mutu suatu arsitektur gereja tergantung pada kepada kepekaan dan ketekunan jemaat dalam menilai peranannya dalam masyarakat (Komisi Liturgi Gereja, 1990). Adapun gereja di wilayah provinsial Keuskupan Agung Semarang berpedoman pada arah dasar: "Hidup dalam budaya setempat dan bersama saudara yang berkehendak baik melaksanakan semangat persaudaraan di tengah masyarakat dan menciptakan tatanan hidup demi kesejahteraan bersama."

Hal itu tidaklah mudah. Sekelompok umat yang berkumpul untuk merencanakan sebuah gereja dewasa ini menghadapi tugas yang sulit. Selain masalah 'harga ekonomi yang harus dibayar untuk suatu proyek pembangunan gereja, adanya terlalu banyak pilihan sering membuat jemaat yang diwakili panitia pekerja gereja menjadi 'kikuk". Setelah pengalaman berharga dari beberapa kasus membangun yang hanya sekedar untuk dikagumi - dan memang mengagumkan tetapi ternyata kurang memenuhi kebutuhan jemaat - maka perencanaan gereja dikembalikan kepada kepentingan jemaat.

Dalam hal ini komponen terpenting untuk diperhatikan adalah liturgi atau peribadatan yang dibentuk oleh hirarki bersama-sama dengan jemaat sebagai subyeknya dan setting di mana bangunan gereja itu sendiri berada (Komisi Liturgi, 1990). Liturgi sendiri mempunyai konsep, bentuk dan tuntutan-tuntutan tentang tata ruang, tetapi kesemuanya bergantung pada: hirarki, jemaat dan setting yang ada (lihat skema / diagram pada di bawah berikut ini).

Uraian dan kajian tentang komponen yang terlibat dalam pemrograman dilakukan bersama-sama dengan proses dan metode pemrograman untuk arsitekturnya.

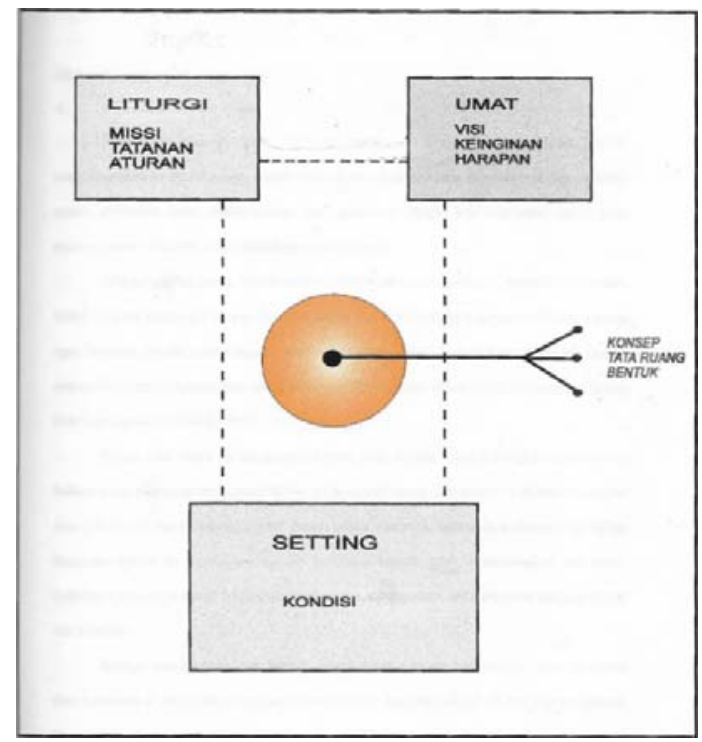

Gambar 1. Komponen Kajian Untuk Pemrograman

3. PROSES PEMROGRAMAN

Sumber: Kajian Penulis

a. Komponen Pemrograman

Hirarki dan Jemaat Awam

Jemaat pada dasarnya dipisahkan ke dalam pengertian hirarki dan awam. Hirarki, seperti yang dimaksudkan dalam gereja, adalah Paus, para uskup dan para pembantunya yaitu pastor pastor; sedangkan Awam adalah jemaat pada umumnya. Dengan kata lain: hiraki adalah para pejabat gereja sedangkan awam adalah masyarakat gereja.

Sebagai pejabat gereja, hirarki ditandai dengan jabatan imamat yang berasal dari Kristus. Untuk itu para imam atau para pastor ditahbiskan oleh Allah melalui perantaraan Uskup dan dengan demikian mereka secara khusus mengambil bagian dalam imamat Kristus. Hirarki berhak merayakan upacaraupacara suci sebagai pelayan Dia (Kristus) dalam liturgi dengan perantaraan RohNya (Konsili Vatikan II, 1967).

Liturgi oleh sebab itu mempunyai tempat yang khusus dalam kehidupan umat kristen, bahkan dapat dikatakan liturgi menjadi puncak kegiatan jemaat dan sumber dari mana mengalir segala kekuatan dan 
kehidupan jemaat. Setiap jemaat mempnyai kebiasaan berkumpul dan dalam himpunan jemaat itu mereka memuji dan bersyukur kepada Allah, mengenangkan dan menghadirkan karya-karya agung Allah, memanjatkan doa, mewujudkan dan merayakan kerajaan damai dan keadilan.

Sebagai doa bersama oleh jemaat, liturgi dapat sungguh berkembang kalau dirayakan dalam suasana di mana jemaat merasa krasan, terlibat dan komunikatif. Di lain pihak ungkapan liturgi diharapkan mengikuti jaman atau up to date, bahkan kalau perlu melakukan pembaharuan melalui pemahaman dan komunikasi simbol-simbol dalam liturgi. Missi liturgis ini dinyatakan dalam Konstitusi Liturgi pasal 34: "Upacara-upacara hendaknya sederhana, melibatkan jemaat, singkat, jelas dan bermakna, sebagai suatu perayaan syukur dan pujian atas kehidupan yang adalah anugerah Allah semata."

Misi tersebut di atas yang kemudian diterjemahkan ke dalam tatanan dan aturan, tertulis maupun tidak tertulis, menjadi wewenang jemaat (hirarki) untuk memandu jemaat (awam). Awam pada dasarnya tidak mengambil pusing dengan tatanan dan aturan yang ada karena pada dasarnya tidak tahu, tetapi awam berperanan besar dalam penghayatan dan pengalaman liturgi. Dari pengalaman dan penghayatan ini awam menyampaikan harapan dan keinginannya kepada hirarki. Sesudah Konsili Vatikan II, awam semakin berperan dan terlibat dalam liturgi, termasuk dalam hal perencanaan dan pembangunan gereja.

Pada saat ini setiap usulan tentang perencanaan gereja harus berasal dari awam dan bukan hirarki. Dalam hal ini hirarki hanya bertindak sebagai pendukung dan pengarah saja. Maka seperti sudah diuraikan sebelumnya, pembentukan panitia perencanaan adalah sesuatu yang mutlak sifatnya. Melalui panitia inilah hirarki bersama-sama awam dapat menyusun pemrograman dan perencanaan tata ruang dan bangunan melalui mekanisme partisipasi dan konsultasi. Adapun situasi gereja sendiri yang bukan merupakan organisasi ekonomi, melainkan organisasi sosial, mensyaratkan prosedur kerja bertahap dan memakan waktu yang lama.

Persiapan untuk membentuk panitia dan mengkaji informasi maupun bahan yang akan dipergunakan dalam perencanaan dimulai sejak Januari 1993. Pada Bulan Juni 1993, melalui rapat Dewan Paroki dibentuk panitia resmi. Pada bulan berikutnya panitia ini segera bekerja untuk mengusulkan program maupun rencana yang disusun secara bertahap mengikuti perkembangan informasi yang terjadi dan juga melalui kajian atas setiap keputusan dalam setiap tahap perencanaan (Juli 1993 - Juni 1995). Pada tahap yang ketiga (Juli 1994 - Juni 1995) mulai dipersiapkan rencana proyek secara skematis yang kemudian dikembangkan dalam rancang bangun untuk arsitekturnya sampai didapatkan ijin membangun. Perlu dicatat di sini, bahwa pada suatu tahap terjadi perubahan pada aspek tertentu dan pada tahap yang kemudian berkaitan dengan aspek yang lain. Pada akhirnya harus diakui bahwa peran Keuskupan Agung semarang dalam kapasitasnya sebagai hirarki gereja lebih menentukan dari pada usulan dari pihak jemaat awam. Hal ini selanjutnya akan dibahas dalam proses pemrograman.

\section{Setting Arsitektural}

Lokasi gereja yang terletak di kawasan pusat kota menjadikan komponen setting dalam pemrograman ini sangat menentukan. Faktor letak ini pula yang menjadi pertimbangan di mana gereja Kidul Loji yang semula adalah gereja paroki yang kecil meningkat derajatnya menjadi gereja besar karena menjadi pusat gereja di Yogyakarta yakni; Gereja Kevikepan Yogyakarta Lingkungan gereja yang sudah terbentuk dan mapan juga menuntut pertimbangan tertentu dalam pemrogramannya. Kawasan tersebut dikenal sebagai colonial square dengan suatu gugusan bangunan yang sudah memiliki kontinuitas visual yang khas: Gedung Agung, Senisono, Bank BNI, Kantor Pos Besar, Bank Indonesia, Benteng Vredeburg, Pasar Gede 'Beringhardjo', Socioteit Militaire, Tio Ciu, Sekolah dan Susteran Marsudirini, Bruderan Fransiskan dan Gereja Kidul Loji itu sendiri.

Renovasi Senisono dan Pasar Gede, pembangunan monumen, tata hijau dan taman parkir, pembangunan gedung baru' Bank Indonesia, pengembangan Kawasan Benteng Vredeburg dan Kantor Pos Besar menjadikan lingkungan tersebut semakin tertata apik dan kekhasan settingnya semakin menonjol. Pada saat yang sama fenomena kakilima, kepadatan pengunjung dan bercampurnya moda kendaraan pada kawasan tersebut menimbulkan pada pengaturan traffic dan parkir. Aspek-aspek ini menjadi pembahasan dalam menyusun program untuk Gereja yang direncanakan.

Status tanah wakaf itu sendiri juga memerlukan kebijakan dari Keuskupan Agung Semarang menyesuaikan peruntukan tanah wakaf tersebut - dengan membentuk sistem setting terbagi dua: lahan gereja dan pastoran yang lama sebagai area pengembangan kompleks gereja (dan pastoran) yang baru sementara lahan bekas gedung percetakan Kanisius sebagai area KantorPusat Vikep Yogyakarta.

Dengan kata lain meskipun secara kuantitatif lahan kompleks gereja bertambah luas namun kenyataannya secara kualitatif justru berkurang karena peningkatan peran dan kegiatan yang baru; oleh sebab itu diperkirakan kemungkinan pengembangan tata ruang baik secara horisontal maupun vertikal. 


\section{b. Tahapan Proses Pemrograman}

\section{Tahap Pertama}

Pemrograman diawali dengan mengolah semua informasi awal yang masuk. Data primer maupun sekunder yang diperoleh kemudian dikonsultasikan kepada hirarki (romo paroki dan pengurus gereja lainnya). Mekanisme partisipasi dilakukan secara langsung dan tidak langsung. Secara langsung adalah melalui kerja tim secara informal ditentukan tujuan dan sasaran serta persyaratan-persyaratan tuntutan dantampilan tata ruang bangunan dan lingkungan sedangkan secara tidak langsung adalah masukan yang disampaikan melalui panitia atau hirarki. Adapun pada tahap ini belum dilakukan pengambilan keputusan apa pun yang berkaitan dengan program maupun rencana karena untuk sampai pada keputusan tersebut harus dilakukan melalui panitia formal. Apa yang dilakukan team persiapan adalah mengusulkan bahan-bahan dasar yang nantinya melalui mekanisme musyawarah panitia formal memutuskan program dan rencana untuk kemudian dikonsultasikan kepada pimpinan hirarki yaitu romo Vikep dan romo Uskup.

Dengan menggunakan stimuli grafis diajukan program ruang dan bentuk bangunan agar mendapatkan tanggapan dan masukan dari wakil umat maupun hirarki Gereja. Jadi pada tahap ini sudah dilakukan publikasi secara terbatas. Pokok persoalan yang dibahas pada tahap ini adalah kebijakan Keuskupan Agung Semarang untuk mengembangkan kapasitas gereja dari 400 menjadi 1000 jemaat dan juga rencana tata ruang dan bangunan untuk kantor pusat Vikep Yogyakarta. Masukan yang didapat dipergunakan untuk mengembangkan dan menggodok lagi tujuan, sasaran dan persyaratan-persyaratan awal yang telah ditetapkan pada langkah sebelumnya.

Perhitungan secara prediktif jemaat paroki Kidul Loji di masa datang yang relatif statis menurunkan rencana kapasitas besaran ruang gereja dari 1000 orang menjadi 800 jemaat. Ada pun masalah kapasitas yang terjadi pada hari-hari 'padat' terutama pada hari raya Natal dan Paskah, dirasa memadai karena dapat dilakukan pengaturan kebaktian untuk setiap pada hari-hari raya maupun hari Sabtu/Minggu lainnya.

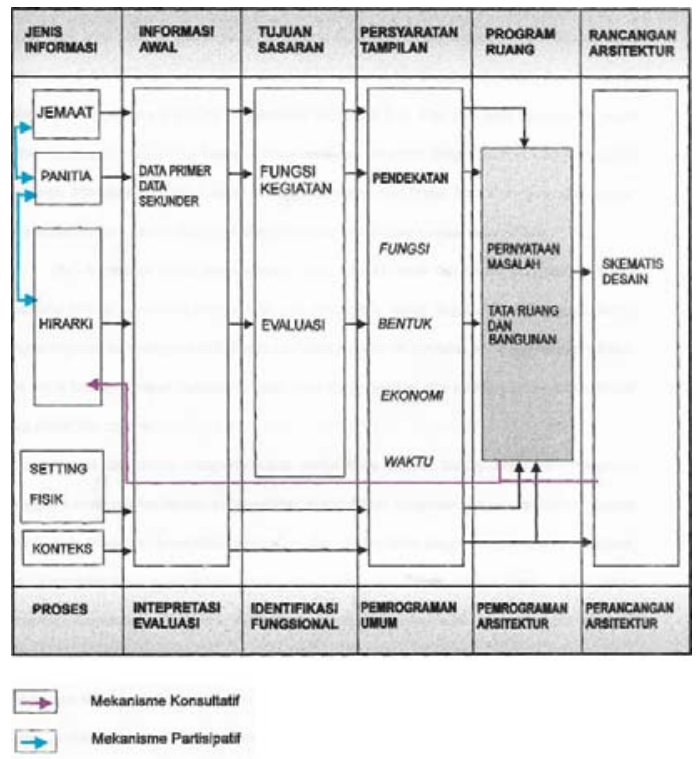

Gambar 2. Proses Pemrograman

Sumber : Data Pribadi

\section{Tahap Kedua}

Usulan pemrograman dan rencana yang berikutnya sudah dapat dipublikasikan kepada jemaat yang lebih luas maupun kepada Keuskupan Agung Semarang karena sudah melalui panitia formal yang dibentuk oleh Dewan Paroki Gereja Kidul Loji dan disetujui oleh Romo Vikaris Episkopalis Yogyakarta. Publikasi ini mendapat tanggapan luas. Dan dari fakta lapangan dijumpai bahwa tanggapan yang paling banyak datang terutama berkaitan dengan bentuk dan penampilan bangunan. Masukan yang tidak kalah pentingnya datang dari Dinas Tata Kota berkaitan dengan penyediaan fasilitas parkir dengan prediksi kepadatan pusat kota sampai tahun 2005.

Dari komponen kajian pemrograman yaitu: hirarki, umat dan setting bangunan akhirnya diusulkan konsep zona atau pendaerahan dan pemisahan antara kegiatan religius untuk liturgy dengan kegiatan 
non religius untuk fungsi perkantoran. Hal ini terutama berkaitan dengan tekanan dari pihak hirarki maupun banyaknya umat yang menginginkan dan mengharapkan ruang ibadat yang sakral dan tenang.

Usulan dan upaya mempertahankan gereja lama melalui konsep konservasi bangunan dianggap kurang relevan dengan permasalahan kompleksitas bangunan yang direncanakan, apalagi setelah pada tahap ini diupayakan pemisahan dan pendaerahan fungsi religius dan non religius, yang konsekuensinya memerlukan lahan yang lebih luas. Tetapi karena panitia tidak dapat mengambil keputusan mana yang lebih baik antara konservasi atau pengembangan akhirnya keputusan diambil alih oleh pihak Keuskupan Agung Semarang dengan rencana membongkar gereja lama seluruhnya dan mengganti bangunan yang baru. Keputusan ini berdasarkan pada dua alasan: pertama, secara fisik bangunan sudah tidak memenuhi persyaratan keamanan karena pada beberapa bagian konstruksi utama sudah keropos dan rapuh sehingga tidak memenuhi persyaratan keamanan untuk bangunan publik; yang kedua, secara teologis membangun gereja dalam arti yang sebenarnya adalah selalu berarti membangun 'yang baru', pada hakekatnya gereja hadir sebagai tanda adanya Perjanjian yang Baru oleh penebusan Yesus Kristus.

Sementara usulan model bangunan gaya Jawa dengan bentuk joglo dari beberapa kalangan jemaat kurang mendapat tanggapan, baik oleh panitia maupun pihak Keuskupan, karena kurang kontekstual terhadap sejarah gereja (kesinambungan bentuk gereja lama dan gambaran adanya pertumbuhan gereja) maupun terhadap kontinyuitas aspek visual dari lingkungan yang ada

\section{Tahap Ketiga}

Dari publikasi yang luas baik melalui proposal yang dikirim dan disebarluaskan ke berbagai pihak maupun pembuatan poster yang besar di depan gereja agar dapat dilihat umat, maka pada tahap ketiga, publikasi kembali menyempit pada lingkungan terbatas yaitu panitia perencanaan, hirarki, anggota dewan gereja dan pihak-pihak yang terlibat langsung. Masalahnya cukup pelik yaitu: sumber pendanaan dan kemampuan membangun.

Menyadari bahwa sumber dana yang paling utama adalah kemampuan swadaya dari jemaat maka diupayakan konsep hemat dan pentahapan dalam perwujudan tata ruang dan bangu nan yang direncanakan. Penghematan dapat dilakukan dengan penggunaan kembali material dari bangunan lama yang masih dapat dipergunakan dan pentahapan pembangunan dengan membangun terlebih dulu bangunan Gereja sebagai pusat dari seluruh area kompleks Gereja dan Kantor Vikaris Episkopalis Yogyakarta.

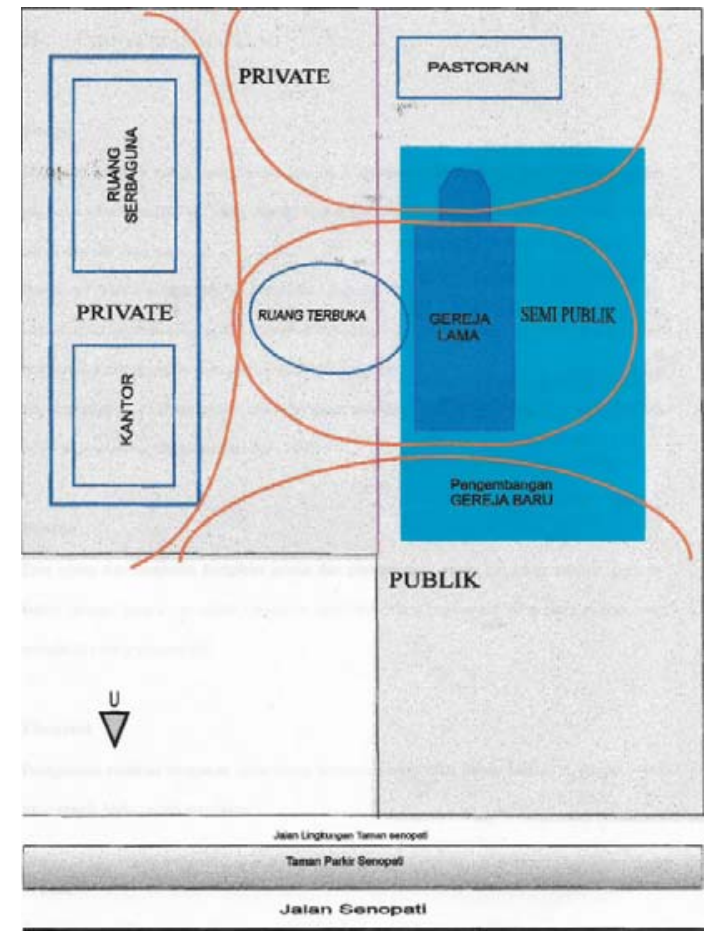

Gambar 3. Skematis Pemrograman Tata Ruang Sumber : Sintesis Peneliti 
Dari stimuli grafis yang dilakukan sejak tahap pertama sampai akhir, maka keterlibatan klien atau dengan kata lain partisipasi jemaat nampak meningkat. Komunikasi secara visual tampaknya sangat membantu arsitek untuk melihat persoalan-persoalan yang secara konsepsual cukup pelik. Banyaknya masukan dan pertimbangan dari jemaat juga membuktikan bahwa stimuli grafis merupakan salah satu bentuk cerapan yang paling jelas. Meski demikian tidak boleh dilalaikan kajian yang teliti pada tataran konsepsualnya.

Dengan menggunakan pembagian William Pena (1969) untuk pernyataan masalah arsitektur maka dapat diusulkan pemrograman untuk tata ruang dan bangunan melalui pernyataan masalah yang berkaitan dengan: Fungsi, Bentuk, Ekonomi dan Waktu.

\section{c. Pernyataan Masalah}

Dari analisis di atas maka dapat disusun Pernyataan Masalah sebagai berikut (sesuai kriteria William Pena, 1969)

\section{- Fungsi}

Bangunan dan tata ruang pusat Gereja Katolik Yogyakarta yang menyediakan fasilitas kegiatan religius/peribadatan (800 jemaat), dan fasilitas kegiatan pelayanan nonreligius/administratif pada lokasi dan site yang lama.

Penyatuan Jalan masuk utama ke kompleks bangunan dipergunakan untuk menuju ke gereja sebagai tempat kegiatan religius dan kemudian ke tempat-tempat kegiatan non-religius, sebuah ruang luar terbuka dipergunakan sebagai ruang publik yang membagi dan memisahkan kegiatan religious dan non-religius.

- Bentuk

Tata ruang dan bangunan kompleks gereja dan perkantoran menggambarkan adanya pertumbuhan jemaat' secara kuantitatif maupun kualitatif dalam lingkungan yang telah mapan serta mengikuti peraturan setempat.

- Ekonomi

Penggunaan material bangunan lama (yang ternyata berasal dari bahan bangunan dengan mutu yang sangat baik) secara terseleksi.

- Waktu

Pentahapan pelaksanaan pembangunan dimulai dari gereja (sebagai inti tata ruang dan kompleks bangunan), kompleks bangunan pastoran dan kemudian kompleks bangunan perkantoran.

\section{Simpulan}

Gereja St. Fransiskus Xaverius Kidul Loji sebagai Gereja Katolik dengan pertumbuhan umat yang semakin banyak akan menyediakan fasilitas kegiatan religius/peribadatan berupa Bangunan Geraja sebagai inti tata ruang dan kompleks gereja. Pembangunan fasilitas kegiatan non-religius / administratif akan dilaksanakan kemudian sesuai dengan tahap yang sudah direncanakan. Sebuah ruang luar terbuka dipergunakan sebagai ruang publik yang membagi dan memisahkan kegiatan religius dan non-religius

Tabel 1. Pemrograman Arsitektur

\begin{tabular}{|l|l|l|}
\hline No. & Permasalahan & Pernyataan Masalah \\
\hline 1. & Fungsi & $\begin{array}{l}\text { - Akan disediakan fasilitas religius (peribadatan) untuk } 800 \text { jemaat } \\
\text { - Disediakan juga fasilitas admin / non-religius pada lokasi dan site lama } \\
\text { - Jalan masuk utama digunakan sebagai akses ke gereja } \\
\text { - Ruang luar terbuka digunakan sebagai ruang publik }\end{array}$ \\
\hline 2. & Bentuk & $\begin{array}{l}\text { Tata ruang dan kompleks gereja dan perkantoran menggambarkan adanya } \\
\text { pertumbuhan jemaat secara kuantitatif maupun kualitatif }\end{array}$ \\
\hline 3. & Ekonomi & Menggunakan material dari bangunan lama dengan mutu baik dan terseleksi \\
\hline 4. & Waktu & $\begin{array}{l}\text { Pelaksanaan pembangunan dimulai dari Gereja (sebagai inti), kompleks } \\
\text { bangunan pastoran dan kemudian bangunan perkantoran }\end{array}$ \\
\hline
\end{tabular}




\section{Referensi}

Asimow, M., 1962, Introduction to Design, Prentice Hall, New Jersey, USA.

Benjamin, Andrew, 1990, Philosophy and Architecture, St. Martin Press, New York

Cross, Nigel, 1984, Development in Design Methodology, John Wiley \& Sons, NY

Heuken, Adolf, 1987, Katekismus Vatikan II, Cipta Loka Caraka, Jakarta

Jones, JC., 1972, Design Methods, John Wiley \& Sons, NY.

Komisi Liturgi KWI.,1990, Tata Ruang Ibadat, Obor, Jakarta

Mangunwijaya, YB., 1988, Wastucitra, Gramedia, Jakarta

Palmer, Mickey C., 1981, The Architect Guide to Facility Programming, Architectural Record Book, NY

Pena, William, dkk., 1969, Problem Seeking, Rowlett \& Scott, Houston

Preiser, Wolfgang FE., 1985, Programming The Built Environmet, van Nostrand, NY

Schirmbeckx, Egon, 1988, Gagasan, Bentuk dan Arsitektur:

Prinsip-prinsip dalam Perancangan Arsitektur Kontemporer, Intermatra, Bandung

Snyder, J., dan Catanese, A., 1979, Introduction to Architecture, Mc. Graw-Hill, NY 